\title{
Variation of the solar cell performance with varying irradiance and temperature in Nigeria
}

\author{
Ike, C. U \\ Department of Physics/Ind. Physics, Nnamdi Azikiwe University, Awka, Nigeria \\ E-mail:nelikechin@yahoo.com
}

Copyright $\odot 2014$ Ike, C. U. This is an open access article distributed under the Creative Commons Attribution License, which permits unrestricted use, distribution, and reproduction in any medium, provided the original work is properly cited.

\begin{abstract}
In Nigeria sun which is in abundance is the most readily available source of solar energy. It does not contribute to an increase carbondioxide, $\mathrm{CO} 2$ and other greenhouse gases in the atmosphere hence non-polluting and requires little or no maintenance. This research work states that solar cells, the basic elements for photovoltaic conversion of solar energy, are especially susceptible to high temperature and irradiation damage primarily due to their large surface. Degradation of electrical and optical characteristics of the solar cells as photo detectors in the increased temperature conditions is one of the most important limitation factors of their application. Since most of the electrical processes in semiconductor devices depend, to some extent, on the temperature, investigations at temperatures higher than room temperature may reveal possible changes in output characteristics of the device. Also the lifetime of the solar PV cell is restricted by the degree of radiation damage that the cell receives. This is an important factor that affects the performance of the solar cell in practical applications. The overall performance of solar cell varies with varying irradiance and temperature. However, both irradiance and temperature affect solar cell efficiency as well as corresponding fill factor also changes. This study gives an idea about how the solar cell performance changes with the change in above mentioned factors in reality and the result is shown by conducting a number experimental.
\end{abstract}

Keywords: Fill Factor; Irradiance; Irradiation; Temperature.

\section{Introduction}

Faced with an alarming increase of energy consumption on one side, and very limiting amounts of available conventional energy sources on the other, scientists have turned to the most promising renewable energy source. Photovoltaic (PV) conversion of solar energy is one of the most up-to-date semiconductor technologies that enable the application of PV systems for various purposes. Also solar PV cells are electronic devices that use p-n junctions to directly convert sunlight into electrical power. A complex relationship between voltage and current is exhibited by the p-n junction in the solar cell. The voltage and current both being a function of the light falling on the cell hence there exists a complex relationship between insolation (sunlight) and output power. Solar cells capture slow-moving low energy electrons. These effects are saturated and cause a fixed energy loss under bight light condition. However, on an overcast day i.e. at lower insolation levels these mechanisms show an increasing percentage of the total power being generated [1]. Too much insolation causes saturation of cells, and the number of free electrons or their mobility decreases greatly. For example, the holes created by the photoelectrons in silicon neutralizes after some time during which they absorb a photoelectron from another atom inside the cell. This results to maximum and minimum production rates.

\section{Theoretical background}

The current and voltage generated by the solar PV cell are related by an I-V characteristic curve. The curve shows an inverse relation between current and voltage. The area under the I-V curve is the maximum power that a panel would produce while operating at maximum current and voltage. This area decreases with increase in solar cell voltage due to 
its increase in temperature [2]. During the period of fluctuations in environmental conditions as a result of variations in temperature and irradiance the I-V curve will change leading to a change in maximum power point. Thus the MPPT algorithm keeps on tracking the knee point.

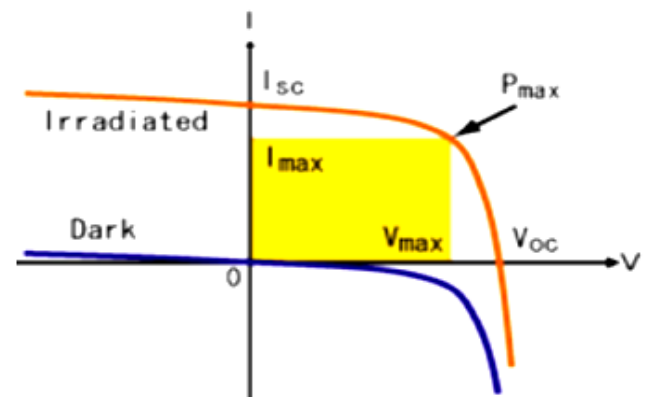

Fig. 1: The (I-V) Curve of Solar Cell Both Under Irradiated and Dark Conditions, Indicating the Maximum Power Operating Region Is the Coloured Region.

Fig. 1 shows two characteristics, i.e. the dark and illuminated characteristics. When the p-n junction is illuminated the characteristics get modified in shape and shift down wards as the photon generated component gets added with the reverse leakage current [3]. The maximum power point can be obtained by plotting the hyperbola defined by $\mathrm{V} * 1=$ constant such that it is tangential to the I $-\mathrm{V}$ characteristics. The voltage and current corresponding to this point are peak point voltage and peak point current. There is one point on the curve that will produce maximum electrical power under incident illumination level. Operating at any other point other than maximum power point will mean that cell will produce maximum thermal power and less electrical power [4].

\section{Effect of irradiance and temperature}

The term irradiance is defined as the measure of power density of sunlight received at a location on the earth and is measured in watt per metre square. Whereas irradiation is the measure of energy density of sunlight. The term irradiance and irradiation are related to solar components. As the solar radiation keeps on changing throughout the day similarly, $\mathrm{I}-\mathrm{V}$ and $\mathrm{P}-\mathrm{V}$ characteristics varies. With the increasing solar irradiation both the open circuit voltage and the short circuit current increase and hence the maximum power point varies. Temperature plays another major factor in determining the efficiency of the solar cell. As the temperature increases the rate of photon generation increases thus reverse saturation current increase rapidly and this reduces the band gap [5]. Hence, this leads to marginal changes in current but major changes in voltage. The cell voltage reduces by $2.2 \mathrm{mV}$ per degree rise of temperature. Temperature acts like a negative factor affecting solar cell performance. Therefore solar cells give their full performance on cold and sunny days rather than on hot and sunny weather. Presently, solar panels are made of non-silicon cells since they are temperature insensitive, thus the temperature remains close to room temperature.

Table 1-4: Voltage Current and Power at Various Irradiance

\begin{tabular}{|c|c|c|c|c|}
\hline $\mathrm{S} / \mathrm{N}$ & Set: 1 & Voltage (V) & Current (mA) & Power (Watts) \\
\hline 1 & & $18.4\left(\mathrm{~V}_{\mathrm{oc}}\right)$ & 0 & 0 \\
\hline 2 & Irradiance & 16.8 & 26 & 0.437 \\
\hline 3 & $50 \mathrm{watt} / \mathrm{m}^{2}$ & 16.5 & 28 & 0.462 \\
\hline 4 & & 15.8 & 32 & $0.506\left(\mathrm{P}_{\max }\right)$ \\
\hline 5 & & 13.1 & 36 & 0.472 \\
\hline 6 & & 4.8 & 38 & 0.182 \\
\hline 7 & & 3.1 & 40 & 0.124 \\
\hline 8 & & 0.8 & 40 & 0.032 \\
\hline 9. & & 0 & $40\left(I_{\mathrm{sc}}\right)$ & 0 \\
\hline $\mathrm{S} / \mathrm{N}$ & Set: 2 & Voltage (V) & Current (mA) & Power (Watts) \\
\hline 1 & & $19.0\left(\mathrm{~V}_{\mathrm{oc}}\right)$ & 0 & 0 \\
\hline 2 & & 18.9 & 28 & 0.529 \\
\hline 3 & Irradiance: & 18.6 & 34 & 0.632 \\
\hline 4 & 69watt $/ \mathrm{m}^{2}$ & 18.4 & 40 & 0.736 \\
\hline 5 & & 17.9 & 46 & 0.828 \\
\hline 6 & & 16.0 & 58 & $0.928\left(\mathrm{P}_{\max }\right)$ \\
\hline 7 & & 12.1 & 70 & 0.847 \\
\hline 8 & & 5.4 & 72 & 0.389 \\
\hline 9. & & 0 & $72\left(\mathrm{I}_{\mathrm{sc}}\right)$ & 0 \\
\hline
\end{tabular}




\begin{tabular}{|c|c|c|c|c|}
\hline $\mathrm{S} / \mathrm{N}$ & Set: 3 & Voltage (V) & Current (mA) & Power (Watts) \\
\hline 1 & & $19.7\left(\mathrm{~V}_{\mathrm{oc}}\right)$ & 0 & 0 \\
\hline 2 & Irradiance: & 19.5 & 30 & 0.585 \\
\hline 3 & $117 \mathrm{watt} / \mathrm{m}^{2}$ & 19.0 & 48 & 0.912 \\
\hline 4 & & 18.1 & 70 & 1.267 \\
\hline 5 & & 17.8 & 76 & $1.3537\left(\mathrm{P}_{\max }\right)$ \\
\hline 6 & & 10.8 & 94 & 1.015 \\
\hline 7 & Irradiance: & 3.2 & 96 & 0.307 \\
\hline 8 & $117 \mathrm{watt} / \mathrm{m}^{2}$ & 0.3 & 96 & 0.029 \\
\hline 9. & & 0 & $96\left(I_{s c}\right)$ & 0 \\
\hline $\mathrm{S} / \mathrm{N}$ & Set: 4 & Voltage (V) & Current (mA) & Power (Watts) \\
\hline 1 & & $19.9\left(\mathrm{~V}_{\mathrm{oc}}\right)$ & 0 & 0 \\
\hline 2 & & 18.9 & 32 & 0.598 \\
\hline 3 & Irradiance: & 18.4 & 44 & 0.810 \\
\hline 4 & $168 \mathrm{watt} / \mathrm{m}^{2}$ & 18.1 & 74 & 1.339 \\
\hline 5 & & 17.6 & 86 & 1.514 \\
\hline 6 & & 14.8 & 126 & $1.865\left(\mathrm{P}_{\max }\right)$ \\
\hline 7 & & 10.3 & 130 & 1.339 \\
\hline 8 & & 4.2 & 130 & 0.546 \\
\hline 9. & & 0 & $130\left(\mathrm{I}_{\mathrm{sc}}\right)$ & 0 \\
\hline
\end{tabular}

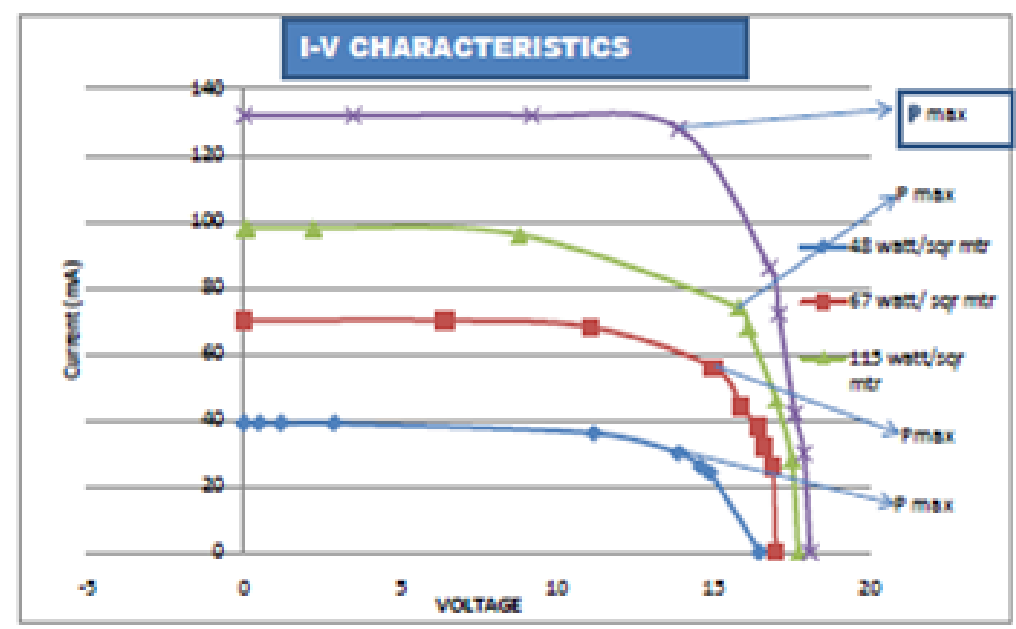

Fig. 2: The I - V Curve at Various Irradiance Level and the Corresponding Maximum Power Point.

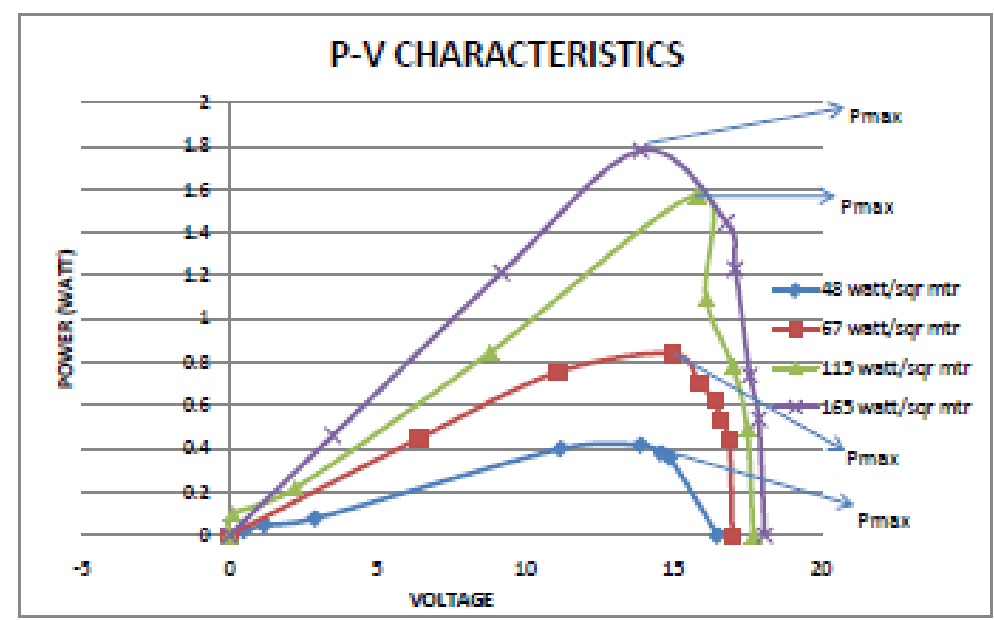

Fig. 3: The $P$ - V Characteristics at Four Different Irradiance Levels. 
Table 2: At Various Temperatures

\begin{tabular}{|c|c|c|c|}
\hline $\mathrm{S} / \mathrm{N}$ & SET: 1 & Voltage (V) & Current (A) \\
\hline 1 & \multirow{5}{*}{ Temp: $28^{\circ} \mathrm{C}$} & $0.80\left(\mathrm{~V}_{\mathrm{oc}}\right)$ & 0 \\
\hline 2 & & 0.74 & 0.2 \\
\hline 3 & & 0.55 & 2.1 \\
\hline 4 & & 0.30 & 3.3 \\
\hline 5 & & 0 & 4.5 \\
\hline $\mathrm{S} / \mathrm{N}$ & SET: 2 & Voltage (V) & Current (A) \\
\hline 1 & \multirow{5}{*}{ Temp: $48^{\circ} \mathrm{C}$} & $0.70\left(\mathrm{~V}_{\mathrm{oc}}\right)$ & 0 \\
\hline 2 & & 0.68 & 0.3 \\
\hline 3 & & 0.50 & 2.4 \\
\hline 4 & & 0.44 & 3.8 \\
\hline 5 & & 0 & 4.6 \\
\hline $\mathrm{S} / \mathrm{N}$ & SET: 3 & Voltage (V) & Current (A) \\
\hline 1 & \multirow{5}{*}{ Temp: $28^{\circ} \mathrm{C}$} & $0.65\left(\mathrm{~V}_{\mathrm{oc}}\right)$ & 0 \\
\hline 2 & & 0.51 & 0.9 \\
\hline 3 & & 0.42 & 1.7 \\
\hline 4 & & 0.31 & 2.6 \\
\hline 5 & & 0 & 3.8 \\
\hline
\end{tabular}

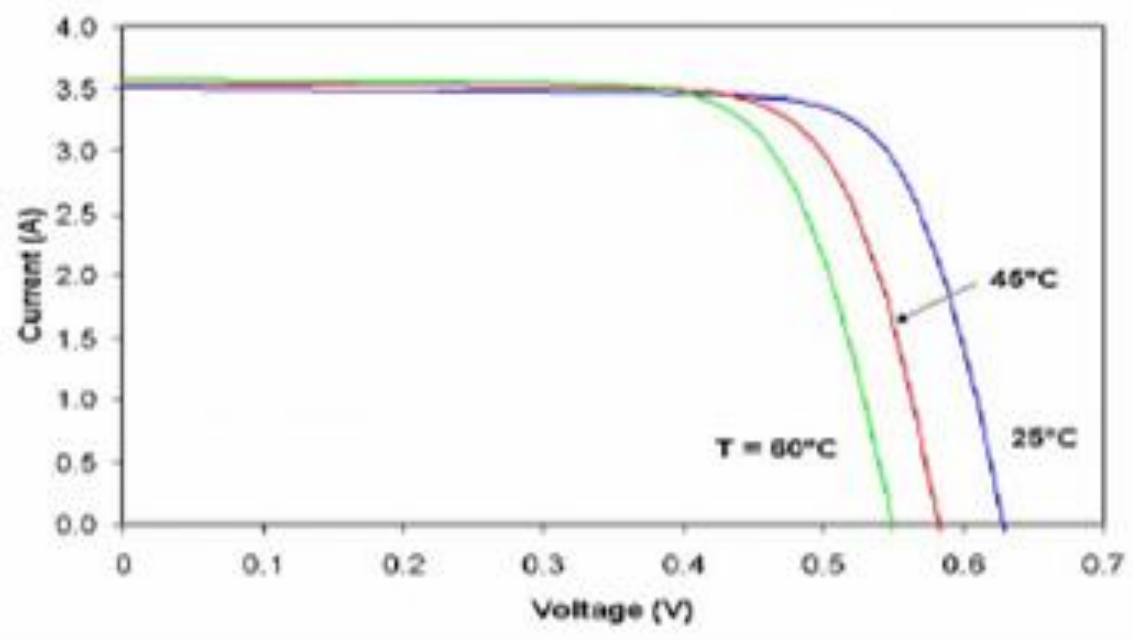

Fig. 4: Variation of I - V Curve With Temperature

\section{Fill factor}

The fill factor which is denoted as FF is a parameter that helps in characterizing the non-linear electrical nature of the solar cell. Fill factor is defined as the ratio of the maximum power from the solar cell to the product of $V_{o c}$ and $I_{s c}$, and it gives an idea about the power that a cell can produce with an optimal load under given conditions, $P=F F \times V_{o c} \times I_{s c}$. The quantity fill factor is noted as an indicator of quality of cell. When the fill factor approaches unity it indicates that the quality of cell gets better [6]. One can improve fill factor in many ways.

Table 3: Variation of irradiance with Fill factor

\begin{tabular}{llll}
\hline S/No & Irradiance $\left(\right.$ Watt/M $\left.{ }^{2}\right)$ & Intensity (Lux) & Fill Factor \\
\hline 1 & 50.0 & 610.0 & 0.63 \\
2 & 68.0 & 1005.0 & 0.66 \\
3 & 114.0 & 2010.0 & 0.72 \\
4 & 154.0 & 3520.0 & 0.75 \\
\hline
\end{tabular}




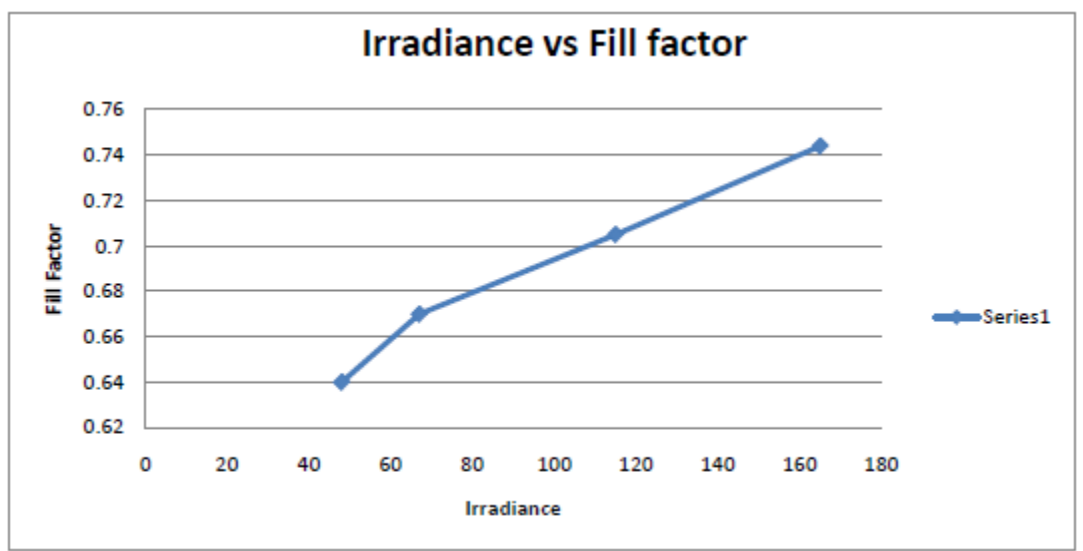

Fig. 5: Variation of Fill Factor with Varying Irradiance

\section{Analysis and conclusion}

The graphs in figs. 2 to 4 showed the variation of the current and voltage at various irradiance levels. The corresponding maximum power points were also indicated. Again with the increase in temperature the rate of photon generation increases thus reverse saturation current increases rapidly and this results on reduction in band gap. Finally, it was observed that this leads to marginal changes in current but major changes in voltage.

\section{References}

[1] J. L. Barth, and C. S. Dyer, Space, atmospheric and terrestrial radiation environments, IEEE Transactions on Nuclear Sciences, (2003), 50(3), 466-482. http://dx.doi.org/10.1109/TNS.2003.813131.

[2] H. K., Osman, K. C. Leong, and R. K. Kannan, Life cycle assessment study of solar PV systems, Solar Energy, (2006), 80, 555 - 563.

[3] A. O. Jesuleye, and W. O. Siyanbola, Solar electricity demand analysis for improved access to electricity in Nigeria, Nigeria Journal of Solar Energy, (2008), 19 (1), $136-141$.

[4] M. Alurralde, A. A. Burlon, and A. J. Kreiner, Experimental and theoretical radiation damage studies on crystalline silicon solar cells, solar Energy Materials and Solar Cells, (2004), Vol. 82, $532-542$.

[5] D. W. Meduguand, and T. Yakubu, Estimation of mean Monthly global solar radiation in Yola-Nigeria, Advances in Applied Science Research, (2011), 2 (2) $414-421$.

[6] O. Adegbeno, Challenges and prospect of energy efficiency and conservation, Journal of Energy Policy, Research and Development, (2011), 1 (1), 104-110. 